\title{
Endogenous and Exogenous Determinants of Agricultural Productivity: What Is the Most Relevant for the Competitiveness of the Italian Agricultural Systems?
}

\author{
Adele Coppola ${ }^{1}$, Sara Ianuario ${ }^{1}$, Gaetano Chinnici ${ }^{2}$, Giuseppe Di Vita ${ }^{2}$ Gioacchino Pappalardo ${ }^{2}$, \\ Mario D'Amico ${ }^{2}$ \\ ${ }^{1}$ Department of Agricultural Sciences, University of Naples Federico II, Via Università 96, 80055 Portici \\ (Naples), Italy \\ 2 Department of Agriculture, Food and Environment (Di3A), University of Catania, Via S. Sofia 98-100, \\ 95123 Catania, Italy
}

\begin{abstract}
Several factors are deemed to influence farms' economic performance and competitiveness: endogenous characteristics, such as farm structure and entrepreneur's features, as well exogenous factors related to the infrastructure endowment, networks and immaterial factors. A deeper knowledge of the role each factor plays in different geographical areas can help to better address the rural policies and to improve their efficacy. In this respect, the present study aims at analyzing how factors that potentially affect competitiveness differ within Italian agriculture and the way those factors act on the economic performance of agriculture at provincial level. The analysis was carried out in two steps. First, in order to define the main characteristics of the Italian agricultural systems a Principal Component Analysis (PCA) has been carried out using data collected by the last Italian Agricultural Census, carried out in 2010, at provincial level and component scores have been used to characterize provincial agricultural systems. In a second step, PCA results were used as explanatory variables in regression models to evaluate their relationship with agricultural productivity and performance indicators at provincial level. The work highlighted two main results. First, agricultural differentiation factors identified in the PCA discriminate two main territorial agricultural models linked to different agricultural systems organization and development strategies. Secondly, the determinants of agricultural productivity and performance are mainly endogenous to the sector and only few context indicators seem to act as explanatory variables.
\end{abstract}

\section{Keywords}

Italian agricultural systems; competitiveness, NUTS3; rural development policy.

Coppola, A., Ianuario, S., Chinnici, G., Di Vita, G., Pappalardo, G. and D'Amico, D. (2018) "Endogenous and Exogenous Determinants of Agricultural Productivity: What Is the Most Relevant for the Competitiveness of the Italian Agricultural Systems?", AGRIS on-line Papers in Economics and Informatics, Vol. 10, No. 2, pp. 33-47. ISSN 1804-1930. DOI 10.7160/aol.2018.100204.

\section{Introduction}

Over last decade farm competitiveness has become a topic of increasing relevance in the EU agricultural and rural policies. During the past programming period, the actions aimed at improving the competitiveness of the agricultural and forestry sectors have been included in the first thematic axis of Rural Development Programs (RDP) and, although the logic of intervention in the new rural policy is quite different, fostering the competitiveness of the agricultural farms remains one of the long term strategic objectives for the EU rural development policy from 2014 to 2020. This goal should be pursued through priorities that reflect the thematic objectives of the Community Support Framework. In particular, agriculture competitiveness can require a focus on (Reg. EC 1305/2013):

- $\quad$ "fostering knowledge transfer and innovation in agriculture, forestry, and rural areas (...);

- enhancing farm viability and competitiveness of all types of agriculture in all regions and promoting innovative farm technologies and the sustainable management of forests;

- promoting food chain organization, including processing and marketing of agricultural products, animal welfare and risk management in agriculture (...)". 
The measures through which priorities should be achieved act on one or more factors which are considered determinants of farm and sector competitiveness and RDPs should include the support to training and advisory services, investments on physical assets, aids to young farmers and to the setting-up of producer groups and organizations, interventions aimed at the development of horizontal and vertical co-operation among supply chain actors, and so on.

Indeed, several factors are deemed to influence farms' economic performance and competitiveness. Competitiveness has been analyzed by adopting different approaches and perspectives (micro/ macro, theoretical/empirical, static/dynamic), which focused on determinants both internal and external to the farm/sector: the economies of scale and scope, firm's organization, human capital, social capital, networks and inter-firms' relationship, socio-economic context, governance models and policies.

A deeper knowledge of the role each factor plays in different geographical areas can help to better address the rural policies and to improve their efficacy (Bartolini and Viaggi, 2013; D'Amico et al., 2013). In this respect, the goals of the present study are twofold: (1) first, it aims at analyzing how factors that potentially affect competitiveness differ within Italian agriculture; (2) second, it wants to test the way those factors act on the economic performance of agriculture at NUTS3 level.

In particular, the paper intends to explore how much the agricultural economic performance depends on specific structural characteristics and farming typologies as well as on other variables such as human capital and farm strategies. Moreover, as the analysis was carried out at NUTS3 level (the Italian provinces), the work can provide useful insight to verify whether the economic performance fits a territorial systematic pattern or it is more linked to specific local factors.

The paper is organized as follows. It begins with a short review of the competitiveness factors that previous studies have highlighted as determinants in farms' economic performance. After the description of data and methods used in the analysis, the following section presents the main results of the research and last paragraph draws some conclusions and implications for future rural policy.

\section{The determinants of the competitiveness}

Studies that dealt with competitiveness took into account several dimensions of this complex concept - cost superiority, productivity, efficiency, profitability, market performance and used different approaches to measure it (Man et al., 2002; Latruffe, 2010; Di Vita et al., 2015). This depends on the disciplinary approach of the researcher and on the level (firm/industry/region/nation) at which competitiveness is analyzed, affecting both the definition of competitiveness used and the list of factors that are considered its determinants/drivers.

In the firm's level perspective, competitiveness is generally conceived of in terms of long-term performance of the firm with respect to its competitors. As a consequence, the competitiveness can be viewed as: i) long term-oriented; ii) a controllable characteristic, as it relates to the resources and capabilities of the firm; iii) a relative and iv) dynamic concept (Man et al., 2002). At the firm's level, competitiveness has been mainly analyzed in terms of productivity and efficiency and studies have been focused on the effect of the internal firm's factors (Amit and Schoemaker, 1993), the external environment (Nickell et al., 1997; Fried et al., 1999), or the entrepreneur's characteristics (Cooper and Gimeno Gascón, 1992; Man et al., 2002).

With reference to the size-efficiency relationship, larger firms are assumed to be more efficient because of specialization and scale's and scope's effects (Seth, 1990; Balk, 2001), but size can influence the firm's competitiveness also because it is an approximation of larger resources availability and thus implies the possibility to innovate and to reach a wider market (Schumpeter, 1934). However, the direct size-efficiency relationship has not always been proved and, on the contrary, some studies argued that efficiency is higher for smaller firms because of their flexibility and better adaptation ability (Scherer, 1991; Halkos and Tzeremes, 2007). Moreover, the size-efficiency link could hide the effect of other variables, such as the firm's organization and the management factor (Geroski, 1998), and the characteristics of the industry where the firm competes -concentration, entry and exit barriers- can influence the profit rate and growth (Schumpeter, 1934, Di Vita et al., 2014). As entrepreneur characteristics are concerned, human capital quality has been linked to firms' efficiency because of its influence on the propensity to risk and to innovate. The manifold studies on this issue have mainly focused on features such as age, experience and education, as well as on gender (Doss 
and Morris, 2000; Man et al., 2002; Latruffe, 2010).

Networks and immaterial factors, such as the institutional environment and the social capital, are deemed to be even more important when a territorial perspective of competitiveness is assumed (Capello et al., 2011; Esposti, 2011). In this approach, the relationship between territory and competitiveness has been investigated by two main points of view. On one side, the attention has been focused on the role the territory plays in firm and system competitiveness (Maskell and Malmberg, 1999; Budd and Hirmis, 2004). On the other side, the concept of competitiveness has been applied to a territorial dimension and the analysis has concerned the performance of regions and nations and the factors that potentially affect the competitive advantages. Concerning this last approach, the basic assumption is that countries compete with each other in the same way corporations do and the attention is mainly focused on the international trade (Porter, 1990; Fagerberg, 1996; Krugman, 1996; Budd and Hirmis, 2004). The territory matters for firm competitiveness not only because the infrastructural endowment affects average costs of production, but also because of collective learning processes. These can be considered as territorially specific and result in a "socialized growth of knowledge embedded in the internal culture of firms and in the local labour market" (Camagni, 2002).

With regard to the agricultural sector, several empirical studies have tested the effect of the one or the other factor.

Human capital has been related to farm performance mainly because it influences the decision-making with respect to adoption of new technologies (Mathijs and Vranken, 2001; Adrian et al., 2005), intensity of production and land use (Solano et al., 2006), diversification strategies (Ondersteijn et al., 2003), access to credit and to complementary inputs (Doss and Morris, 2000). In particular, farmers' age is inversely linked to competitiveness and previous studies argued that young farmers: i) reach higher economic performance (Carillo et al., 2013); ii) have a higher propensity to invest, because of their longer term horizon (Corsi, 2009); iii) are more able to put innovations into practice. Age can act in the inverse direction and older farmers are more conservative in relation to the uptake of innovation and new management practices. Moreover, other farmers' features can influence the propensity to introduce changes and then the reaching of competitiveness in a dynamic view. Farmer's education level as well as entrepreneur's motivations, which can push him to put innovations in practice, can positively affect farm management and productivity (Prokopy et al.; 2008, Phillips, 1994). Finally, previous research found that the involvement in farm advisory programmes is positively associated with farmers' adoption of best management techniques (Millar, 2010) and recent studies on the propensity of farms to consume services (De Rosa et al., 2013) showed that the farm's structure and the life cycle of family farms, as well as relational aspects, can considerably affect the use of services.

Focusing on territorial determinants of competitiveness, Gellynck et al. (2007) argued that firms participating in regional networks demonstrate stronger innovation competences and are more oriented towards international markets. In this respect, García Álvarez-Coque et al. (2013) found that education, physical access to knowledge centres and the localization in a food specialized industrial districts are the territorial factors mostly affecting innovation (and performance) of the agri-food firms.

Indeed, a complex concept such as competitiveness calls for manifold explanation factors and needs to take into account more than one point of view for its interpretation.

In order to better understand the role of different determinants on competitiveness in the agricultural sector, in this work the most relevant factors highlighted in the literature have been related to competitiveness with reference to the Italian case.

\section{Materials and methods}

To investigate the relationship between agricultural competitiveness and the farm's internal and external determinant factors, a first relevant choice concerned the indicator to measure agricultural competitiveness. In the present work we chose productivity as proxy of competitiveness both because of the level of the product aggregation (sector) and the spatial extension of the analysis (NUTS3) and because of data availability constraints. There are several measures of productivity that can be used as well as different approaches to evaluate them (OECD, 2001): simple partial productivity indicator (ratio between output and one relevant factor) or the more comprehensive Total Factor Productivity (TFP) that takes into account the multifactor dimension of production; indicators evaluated in physical units or in value-added terms. In the present work, 
simple partial productivity indicators, referred to work and utilized area, were used. Moreover, the average farm productivity was analysed as indicator of the farm's ability to remunerate all employed resources and the sustainability of the local agricultural sector in a long-term perspective.

As far as determinants of competitiveness are concerned, the basis hypothesis of the present paper is that it depends on two types of factors. The first ones are endogenous to the farm. They relate to farm structure, quantity and quality of land, capital endowment, production systems, but also to socio-demographic characteristics of the owner, his/her goals and values that result in different management strategies (Hall and LeVeen, 1978; Ordersteijn et al., 2003; Ahearn et al., 2005). Of course, these factors are strongly related one to the other, as land characteristics, factor intensity, defined in terms of capital/land and labour/land ratios, as well as type of farming, both are influenced by and influence the holder' features and strategies.

The second group of factors that affect competitiveness is exogenous to the farm and deal with the context in which the farm operates. As a matter of fact, farm performance can depend on the economic infrastructures, the market development, the characteristics of social capital and network relationships (Ahearn et al., 2005). These can be territorially specific and can affect the ability to reach markets, the way farms interact within the food chain, the possibility of combining in-farm and off-farm work.

Taking that into account, in order to define the main characteristics of the Italian agricultural systems a Principal Component Analysis (PCA) has been carried out using data at NUTS3 level collected by the last Agricultural Census carried out in 2010 . PCA is a multivariate analysis technique that allows synthesizing a large set of interrelated variables in a relatively small number of uncorrelated factors (the principal components). In general, the PCA aims at reducing the dimension of the variables space while maintaining most of the variance of the original variables and is useful to simplify the description of a dataset and to investigate data structures (Abdi and Williams, 2010).

The PCA model is expressed by the following formula:

$Y_{i}=W_{i 1} X_{1}+W_{i 2} X_{2}+\ldots+W_{i p} X_{p}$

where $Y_{i}$, the $i$ component, is a linear combination of the $p$ standardised original variables $X_{l}, X_{2}, \ldots X_{p}$ and $W_{i 1}, W_{i 2}, \ldots W_{i p}$ are the associated weights.

Two preliminary tests are relevant to assess the adequacy of the data to the assumptions of the model specified: Bartlett's test of sphericity and the Kaiser-Meyer-Olkin (KMO) test.

The Bartlett's test allows testing the hypothesis that the correlation matrix coincides with the identity matrix. The test is based on a chi-square transformation of the determinant of the correlation matrix and low values of the test indicate that the hypothesis of identity matrix cannot be rejected and then the use of the factor model might not be appropriate.

The KMO test compares the magnitude of observed correlations with partial correlation coefficients:

$$
K M O=\sum_{i}^{p} \sum_{j \neq i}^{p} r^{2} i j / \sum_{i}^{p} \sum_{j \neq i}^{p} r^{2} i j+\sum_{i}^{p} \sum_{j \neq i}^{p} c^{2} i j
$$

The values of $K M O$ range between 0 and 1: low values of the index suggest the potential inadequacy of the analysis since correlations between two variables cannot be explained by other variables. Kaiser and Rice (1974) suggest that values above 0.7 can be considered satisfactory, while values below 0.5 are substantially unacceptable.

Some issues are very relevant when carrying out a PCA. A critical phase is the choice of the variables to be considered. Original variables should cover all aspects deemed to represent the analyzed phenomenon and reflect the theoretical interrelation model of the researcher. Within groups of original variables the selection can be based on the value of communalities, that is the total variance an original variable shares with all other variables included in the analysis. In this study, taking into account the different endogenous factors that are considered determinants for competitiveness and performance in the agricultural sector, variables were selected to get information on the agricultural activity (crops, farm's size, labour use intensity, irrigated land, quality of land in terms of UAA located in plain), on farmers' characteristics (education, percentage of retired farmers), on market and management strategies (orientation to the market, organic production, processing and diversification of in-farm activities).

Table 1 shows the final set of 19 endogenous variables used in the PCA. The statistical package SPSS (version 20.0) was used to perform the analyses. The adequacy of sampling for PCA 
was tested by means of the KMO and the Bartlett's tests. Values of both tests $(\mathrm{KMO}=0.716$; Bartlett's test $=1,766.26 \mathrm{Sig}$. 0.000) indicate that data are suitable for factor analysis.

\begin{tabular}{|c|c|}
\hline Farm structure & $\begin{array}{l}\text { UAA per holding } \\
\text { Number of livestock per holding } \\
\text { Working days per holding } \\
\text { Share of UAA with green house } \\
\text { endowment }\end{array}$ \\
\hline Quality of land & $\begin{array}{l}\text { Share of irrigated land } \\
\text { Share of plain land }\end{array}$ \\
\hline $\begin{array}{l}\text { Holder's } \\
\text { characteristics }\end{array}$ & $\begin{array}{l}\text { Share of holders with agricultural } \\
\text { degree } \\
\text { Share of retired or housekeeping } \\
\text { holders } \\
\text { Share of holders using ICT }\end{array}$ \\
\hline Production system & $\begin{array}{l}\text { Share of UAA with permanent crops } \\
\text { Share of UAA under cereals production } \\
\text { Share of UAA under labour intensive } \\
\text { crops (vegetables, flowers, fruit) } \\
\text { Share of UAA occupied by vineyard }\end{array}$ \\
\hline Management strategies & $\begin{array}{l}\text { Share of holdings with diversified } \\
\text { activities } \\
\text { Share of UAA under organic crops } \\
\text { Share of holdings participating } \\
\text { to associations and co-operatives } \\
\text { Share of holdings market oriented } \\
\text { Share of UAA with Protected } \\
\text { Designation of Origin (PDO) and } \\
\text { Protected Geographical Indication } \\
\text { (PGI) products } \\
\text { Share of holdings making products } \\
\text { processing }\end{array}$ \\
\hline
\end{tabular}

Source: own processing

Table 1: Agricultural variables used in the PCA.

A second issue in PCA relates to the number of components to extract. Many criteria have been suggested in literature. In the present work, components have been selected on the basis of 1 eigenvalue criteria (Kaiser, 1960), that is only components that account for a variance greater than 1 have been considered ${ }^{1}$.

Another important topic is the interpretation of the components. The components meaning can be deduced by the factor loadings matrix, that contains the correlation between the original variables and each component: the greater the absolute value of the coefficient, the greater the importance of that variable for the component. The interpretation of components can be increased by the rotation

\footnotetext{
${ }^{1}$ Working with standardized variables, components with a variance
} lower than 1 are not better than a single variable of the components' space. In the present study a Varimax rotation has been performed, an orthogonal rotation that minimizes the number of variables that have high loading in a component (Kaiser, 1958).

Once components have been extracted, the factor weights are used in conjunction with original variable values in order to calculate each observation's score. Therefore, the component scores represent the position of each observation in the new component space and are standardized to reflect a z-score: zero values of the components represent the average of the investigated sample, while values above/under zero identify observations above/ under the average as component characteristics are concerned.

As previously underlined, only farms' endogenous variables have been included in the PCA. In a second step of the analysis, PCA results were used as explanatory variables in a regression model together with some indicators at NUTS3 level that can approximate farms' exogenous competitiveness and performance determinants. Data on territorial characteristics were extracted from the database made available by the Department for the Development of Territorial Economies of Italian Government ${ }^{2}$ and refer to year 2011, therefore are compatible with the year of the agricultural census data.

The indicators to test were selected taking into account the main determinant factors underlined in the literature. Some of them can directly affect competitiveness of the agriculture in a territory, such as the infrastructures endowment or the ICT services diffusion that are deemed as critical factors for the efficient functioning of the economy, or human capital quality that is relevant to characterize the local labour market.

Other indicators give information on the viability of the socio-economic system. They can reflect the action of competitiveness factors but, at the same time, can be deemed to favour the development of the agricultural sector. In this group, the growth rate of firms can be considered an indicator of an institutional and economic environment that can be more or less favourable to entrepreneurial development. The rate of openness of the economic system, estimated by the trade value/GDP ratio, is the sign of a dynamic economic system that

\footnotetext{
${ }^{2} \mathrm{http}: / /$ www.tagliacarne.it/banche_dati_e informazione statistica-14/banca_dati_statistica_diset_presidenza_del_consiglio_ dei_ministri-6/
} 
can be determined by the action of territorial competitiveness factors and reflect the existence of intense networks' system and market relationships. Similar meanings can be ascribed to indicators such as the innovation rate, social capital endowment, the rate of crimes and so on.

Three separate regression models have been tested where the dependent variable were labour and land productivity, and the value added per farm at provincial level, such that:

$y_{i}=\mathrm{X}_{i}^{\prime} \mathrm{b}+e_{i}$

$\mathrm{E}\left[e_{i} \mid \mathrm{X}_{i}\right]=0, \quad e_{i} \sim \mathrm{N}[0,1]$ with $i=1, \ldots \ldots, \mathrm{n}$.

where $X^{\prime}$ is the vector of the factor scores and infrastructural and territorial socio-economic characteristics referred to the $i$ NUTS3.

\section{Results and discussion}

\section{The $P C$ analysis}

The PCA extracted five principal components, which explain $77.2 \%$ of the variance (Table 2). Factor loadings matrix can help to interpret the components' meaning. As previously underlined, the loadings represent the correlation between the original variables and each of the extracted components and the higher is the loading, the more the variable is related to the component and allow explaining its meaning. In the analysis of the loadings matrix only minimum values of 0.35 were considered (Overall and Klett, 1972, De Lillo et al., 2007).

The first component account for $22.1 \%$ of the variance of original data and synthesizes the "level of professionalism" of the agricultural activity. In fact, the positive correlation with the number of working days per farm and with the physical size of the holding, as well as with variables such as the owner's educational level and the share of ICT users, gives information on the employment role of the farm and on the holder's skills. Moreover, the negative correlation with the share of owners who are homemakers or retired increases the relevance of the farmer's characteristics in influencing the lower/higher commitment in the farm activity, while the positive correlation with the average number of livestock units indicates that a higher level of professionalism more likely occurs the more the farm is specialized in livestock farming.

The second component differentiates the "quality of resources and market orientation". In particular its positive values identify irrigated crop and/or livestock farming that are market oriented. It includes some variables that refer to natural resources endowment (percentage of land in plain area, percentage of irrigated land), others that identify land use (share of UAA occupied by cereals), some others relating to the market role (percentage of farms whose production is sold to the market, percentage of farms participating to associations and co-operatives). A positive, smaller, correlation also exists between this component and the farmer's educational level, on one side, and the livestock size, on the other side. Then, positive values of the second component are associated with situations with a good quality soil, larger size, livestock farming and characterized by more intense horizontal relationship. On the contrary, negative values of the component identify cases of marginal agricultures in terms either of structural endowment and soil quality, or of production systems.

"Management strategies" are synthesized by the third component that explains $13.6 \%$ of the variance. This component shows a negative correlation with the share of UAA occupied by organic crop, corresponding to a deepening strategy, and a positive correlation with the share of holdings that adopt a diversification strategy following a broadening pattern by expanding in-farm activities (van Der Ploeg and Roep, 2003). Then, from negative to positive values of the third component, the prevailing of deepening vs broadening strategies can be distinguished. The high positive correlation between the component and the weight of farmers using ICT, on one side, and the number of working days per farms, on the other side, highlight that broadening strategies are more likely to occur the higher is the innovation propensity and the more labour intensive is the farming type.

Last two components are directly linked to the farming typology. The fourth one (11.8\% of the variance) is positively related to the share of UAA occupied by permanent crops, vineyard in particular, and by PDO and IGP production ("Permanent crops and quality products' agriculture").

The fifth factor explains $11.2 \%$ of the variance. It is positively related to the weight of horticulture, flowers and fruit crops, and negatively correlated to the average farm size. Therefore, from negative to positive values the components represents 


\begin{tabular}{|c|c|c|c|c|c|}
\hline & \multicolumn{5}{|c|}{ Factors } \\
\hline & $\begin{array}{l}\text { Level } \\
\text { of professionalism } \\
\text { of the agricultural } \\
\text { activity }\end{array}$ & $\begin{array}{l}\text { Quality } \\
\text { of resources } \\
\text { and market } \\
\text { orientation }\end{array}$ & $\begin{array}{c}\text { Management } \\
\text { strategies }\end{array}$ & $\begin{array}{l}\text { Permanent crops } \\
\text { and quality } \\
\text { products' } \\
\text { agriculture }\end{array}$ & $\begin{array}{l}\text { Level } \\
\text { of intensive } \\
\text { agriculture }\end{array}$ \\
\hline Share of retired or housekeeping holders & -0.798 & 0.206 & -0.121 & 0.179 & -0.130 \\
\hline Working days per holding & 0.794 & 0.105 & 0.538 & 0.007 & 0.021 \\
\hline Share of holders with agricultural degree & 0.780 & 0.324 & 0.125 & 0.032 & -0.130 \\
\hline Share of holders using ICT & 0.754 & 0.273 & 0.529 & -0.001 & -0.073 \\
\hline Number of livestock units per holding & 0.752 & 0.304 & -0.022 & -0.125 & -0.081 \\
\hline UAA per holding & 0.679 & 0.213 & 0.077 & -0.274 & -0.396 \\
\hline Share of holdings market oriented & 0.035 & 0.880 & 0.124 & 0.169 & 0.072 \\
\hline Share of plain land & 0.366 & 0.776 & 0.033 & 0.025 & 0.119 \\
\hline Share of UAA under cereals production & 0.191 & 0.755 & 0.001 & -0.167 & -0.245 \\
\hline Share of irrigated land & 0.520 & 0.745 & -0.047 & -0.032 & 0.179 \\
\hline $\begin{array}{l}\text { Share of holdings participating } \\
\text { to associations and co-operatives }\end{array}$ & -0.147 & 0.700 & 0.167 & 0.427 & -0.111 \\
\hline Share of holdings with diversified activities & 0.399 & -0.167 & 0.818 & -0.022 & -0.107 \\
\hline Share of holdings product processing & 0.050 & 0.012 & 0.787 & 0.003 & 0.272 \\
\hline Share of UAA under organic crops & -0.064 & -0.213 & -0.663 & -0.020 & 0.129 \\
\hline Share of UAA occupied by vineyard & -0.130 & 0.141 & -0.078 & 0.890 & -0.034 \\
\hline $\begin{array}{l}\text { Share of UAA with Protected Designation } \\
\text { of Origin (PDO) and Protected Geographical } \\
\text { Indication (PGI) products }\end{array}$ & -0.042 & 0.053 & 0.110 & 0.888 & 0.044 \\
\hline Share of UAA with permanent crops & -0.231 & -0.199 & -0.425 & 0.544 & 0.498 \\
\hline $\begin{array}{l}\text { Share of UAA under labour intensive crops } \\
\text { (vegetables, flowers, fruit) }\end{array}$ & -0.131 & 0.136 & 0.058 & 0.064 & 0.868 \\
\hline Share of UAA with green house endowment & 0.038 & -0.065 & -0.005 & -0.056 & 0.831 \\
\hline$\%$ of explained variance & 22.1 & 18.5 & 13.6 & 11.8 & 11.2 \\
\hline
\end{tabular}

Source: own processing

Table 2: Matrix of factor loadings.

the extensive vs intensive agriculture ("level of intensive agriculture").

To illustrate how the extracted components characterize Italian agriculture, in Figure 1 Italian provinces have been identified by level of component scores according to three classes of values $(1=$ average, when values fall in a range of $\pm 20 \%$ around the average, $2=$ higher and $3=$ lower than average). Some main aspects can be underlined.

Generally speaking, components show a territorial pattern and geographical contiguity often reflects in closeness of component values. This is true when components synthesize features related to physical and environmental conditions, such as quality resources or farming typologies, but keeps to be true with respect to components dealing with management strategies. In particular, values of component 3 are territorially specific and, while farms localized in the North base their development patterns on diversification and processing strategies, in South Italy organic agriculture is a preferential way to increase farm profitability. Thus, agricultural development seems to follow a territorial pattern affected by the exogenous context (Niedertscheider and Erb, 2014).

More in detail, a high level of professionalism, mainly linked to livestock farming, and a well developed association's system are matched to a good resources quality and a strong market orientation in the agriculture of some Northern Italy provinces, localized in the so called Padana Plain. High values of the first component, with a high employment level, bigger size farms and livestock farming systems characterize the agriculture of some Southern provinces in Sardinia, too. Nevertheless, in these last cases quality of resources and market orientation are lower than the average, so that these production systems should be very different from the previous ones, either in terms of farm organization or in terms of economic performance. Low levels of professionalism and/or crop oriented farming 

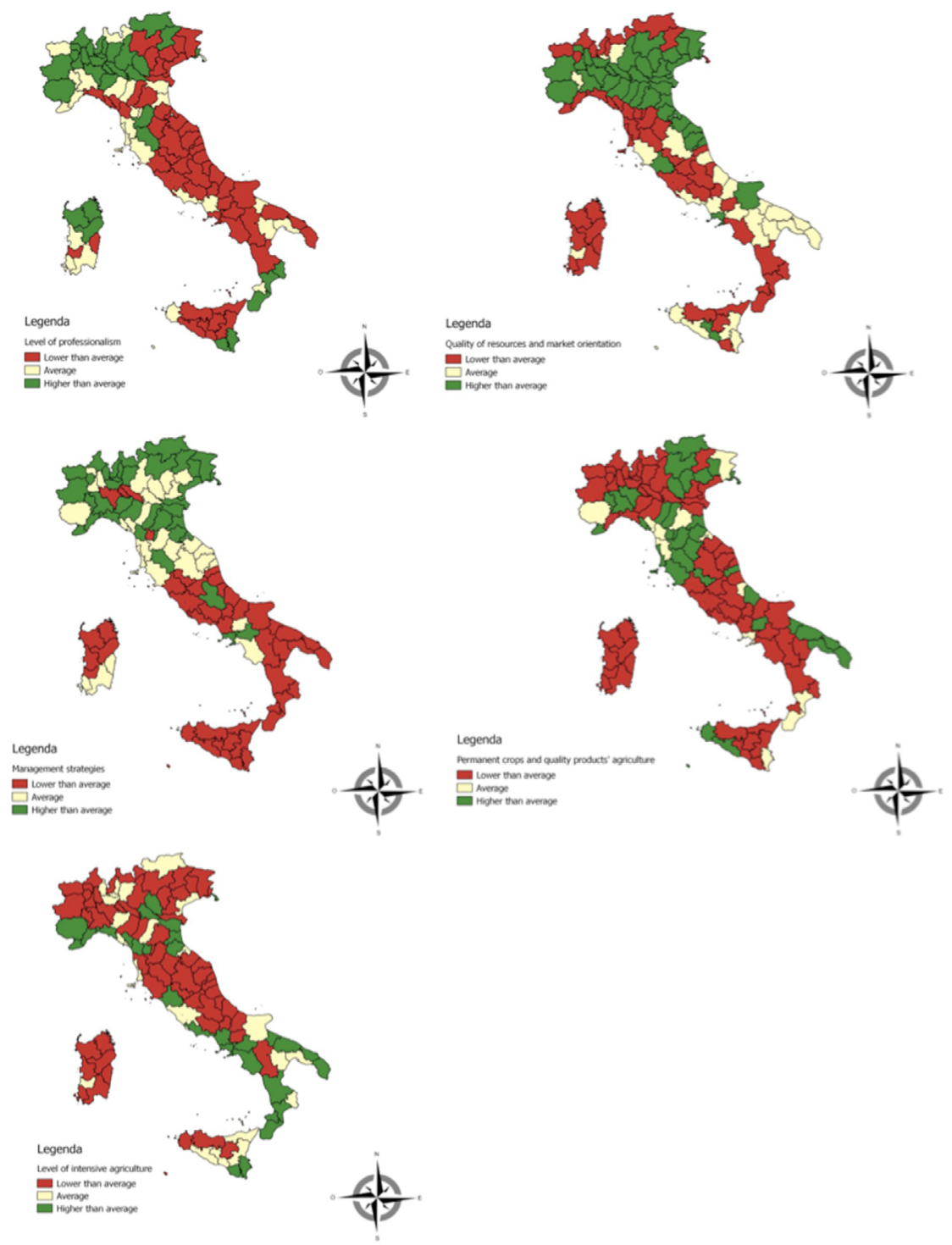

Source: own processing

Figure 1: Italian provinces by class of component values.

systems occur in a context of poorer land quality and natural disadvantages in the Apennine Mountains of Central and South Italy. As far as management strategies are concerned, Southern and Northern provinces are characterized by very different agricultural patterns. The first ones seem mainly oriented towards a deepening strategy based on the organic agriculture, while a broadening pattern better characterizes the Northern agriculture. The product specialization is less territorially defined, but intensive farming typologies (fruit, horticulture and flowers) are more widespread in the South. Anyway, it should be underlined that, even when the production system is similar and a quality pattern has been developed, a higher integration in the food chain and in-farm diversification strategies are more likely to occur in the Northern Italy provinces.

Thus, the differentiation factors identified in the PCA seem to discriminate two main territorial agricultural models and the historical "socio-economic divide" between Southern and Northern Italy also reflect in a different way the agricultural systems organize and choose their development strategies. Territorial differences have been tested by performing the Levene's test to verify the hypothesis of homogeneity of variances followed by the Kruskal-Wallis test on components 1 to 3 and ANOVA for components 
4 to 5 (Tables 3 and 4). Statistical differences were proved for components 1 to 3 , thus confirming that agricultural development pattern can be territorially specific, even if farming typologies are not. Post hoc estimation tests underlined that North/South divide is always verified, while the agriculture of Central Italy is statistically different from North with respect to the first and third component, and from South as component 2 and 3 are concerned.

As competitiveness is concerned, Figure 2 gives a picture of Italy with respect to agricultural labour and land productivity and farm's value added at provincial level. Provinces have been distinguished by considering three classes of values: 1) average, when values fall in a range of $\pm 20 \%$ around the average, 2 ) higher and 3 ) lower than average. Figure 2 highlights two main aspects. Firstly, while labour productivity value is quite similar all over, with only few areas characterized by extreme values, indicators of value added per hectare and per farm show a stronger polarisation. Secondly, the distribution of the value added per farm quite reflects the economic divide between Northern Italy and other areas. That partly might be the result of the contiguity of resources quality and context factors that are the base of the observed territorial economic gap.

Territorial differences of productivity and performance indicators were tested (Tables 5 and 6). Only mean values per farm and per unit of work are statistically different among areas. In particular, value added per farm is statistically lower in Southern provinces with respect to any other areas, while differences exist in value added per unit of work only between South and Centre Italy.

\section{The regression analysis}

The regression analysis was carried out to test the extent the differences previously underlined, both of structural and productive characteristics of Italian agriculture and of farms' management strategies, can affect the value of agricultural productivity at territorial level. Besides the PCA scores, the role of several indicators of the socio-economic context has been tested, such as infrastructural endowment indexes, indicators referred to innovations, to human and social capital and firms' dynamics. Only few of them have been found to be relevant with reference to one or the other dependent variable. The results of regression analyses are reported in tables 7 where only significant coefficients have been reported.

As far as agricultural characteristics are concerned, the first model shows the relationship between labour productivity, on one side, and professionalism level, market orientation of the farm and the level of intensive agriculture,

\begin{tabular}{|l|c|c|c|c|}
\hline Component & Levene's statistics & df1 & df2 & Sig. \\
\hline Level of Professionalism & 6.695 & 2 & 107 & .002 \\
\hline Quality of resources and market orientation & 14.772 & 2 & 107 & .000 \\
\hline Management strategies & 5.296 & 2 & 107 & .006 \\
\hline Permanent crops and quality products' agriculture & 1.494 & 2 & 107 & .229 \\
\hline Level of intensive agriculture & 1.689 & 2 & 107 & .190 \\
\hline
\end{tabular}

Source: own processing

Table 3: Statistical differences of component values by Northern, Central and Southern provinces - Levene's test.

\begin{tabular}{|l|c|c|}
\hline Component & Statistic & Sig. \\
\hline Kruskal-Wallis & & .005 \\
\hline Level of Professionalism & 10.536 & .042 \\
\hline $\begin{array}{l}\text { Quality of resources and market } \\
\text { orientation }\end{array}$ & 6.360 & .000 \\
\hline Management strategies & 55.876 & .481 \\
\hline ANOVA & 0.738 & .297 \\
\hline $\begin{array}{l}\text { Permanent crops and quality } \\
\text { products' agriculture }\end{array}$ & 1.229 & \\
\hline Level of intensive agriculture & & \\
\hline
\end{tabular}

Source: own processing

Table 4: Statistical differences of component values by Northern, Central and Southern provinces - ANOVA and Kruskal-Wallis. 


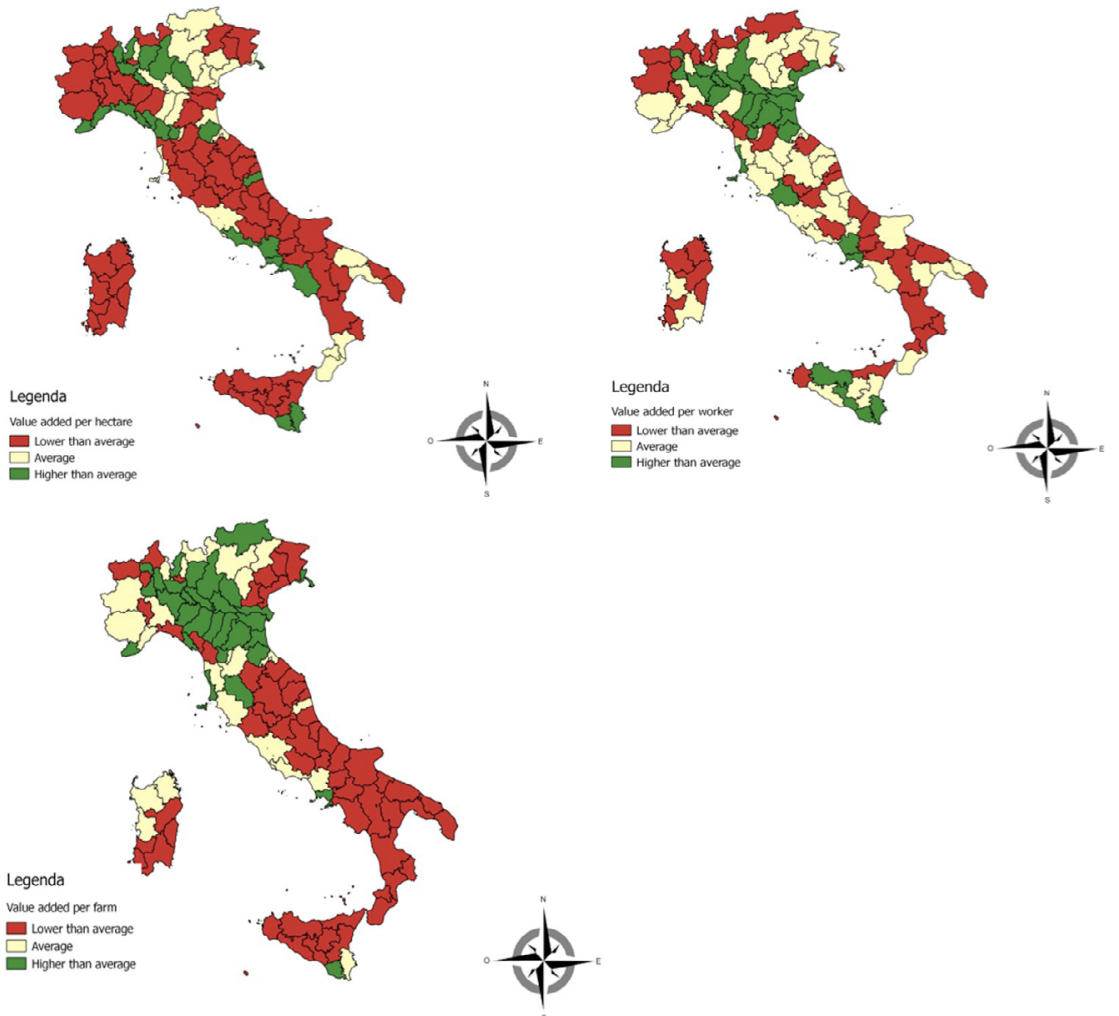

Source: own processing

Figure 2: Italian provinces by class of labour and land productivity and by class of value added per farm.

\begin{tabular}{|l|c|c|c|c|}
\hline Component & Levene's statistics & df1 & df2 & Sig. \\
\hline Value added per unit of work & 1.017 & 2 & 107 & .365 \\
\hline Value added per hectare & .763 & 2 & 107 & .469 \\
\hline Value added per farm & 6.363 & 2 & 107 & .002 \\
\hline Level of intensive agriculture & 1.689 & 2 & 107 & .190 \\
\hline
\end{tabular}

Source: own processing

Table 5: Statistical differences of productivity and performance indicators by Northern, Central and Southern provinces - Levene's test.

\begin{tabular}{|l|c|c|}
\hline Indicators & Statistic & Sig. \\
\hline Kruskal-Wallis & & \\
\hline Value added per farm & 33.695 & .000 \\
\hline ANOVA & & \\
\hline Value added per unit of work & 4.874 & .009 \\
\hline Value added per hectare & 1.601 & .206 \\
\hline Level of intensive agriculture & 1.229 & .297 \\
\hline
\end{tabular}

Source: own processing

Table 6: Statistical differences of productivity and performance indicators by Northern, Central and Southern provinces - ANOVA and Kruskal-Wallis.

on the other side. With respect to the economic context indicators, the positive relationship with the rate of firms' growth and with the openness of the economy confirms the relevance of the networks and the density of economic relationship as factors of territorial competitiveness. As it was expected, agricultural characteristics play a main role in influencing labour productivity. 


\begin{tabular}{|c|c|c|c|}
\hline Component & $\begin{array}{l}\text { Value added } \\
\text { per full time worker }\end{array}$ & $\begin{array}{l}\text { Value added } \\
\text { per hectare }\end{array}$ & $\begin{array}{l}\text { Value added } \\
\text { per farm }\end{array}$ \\
\hline Level of Professionalism & $\begin{array}{c}3.7490 * * * \\
(3.87) \\
\end{array}$ & & $\begin{array}{c}16.9070^{* * *} \\
(10.29) \\
\end{array}$ \\
\hline Quality of resources and market orientation & $\begin{array}{c}7.4796^{* * *} \\
(6.24)\end{array}$ & $\begin{array}{c}-0.4564 * * \\
(2.16)\end{array}$ & $\begin{array}{c}6.0744 * * * \\
(6.3)\end{array}$ \\
\hline Management strategies & & $\begin{array}{c}0.7645^{* * *} \\
(4.54) \\
\end{array}$ & \\
\hline Permanent crops and quality products' agriculture & & $\begin{array}{c}0.4620 * * \\
(2.52)\end{array}$ & \\
\hline Level of intensive agriculture & $\begin{array}{c}4.1569 * * * \\
(3.18)\end{array}$ & $\begin{array}{c}2.4085^{* * *} \\
(6.26)\end{array}$ & \\
\hline Road infrastructure index & & $\begin{array}{c}0.01701 * * * \\
(3.29)\end{array}$ & \\
\hline ICT services index & & & $\begin{array}{c}0.1052 * * * \\
(3.75)\end{array}$ \\
\hline $\begin{array}{l}\text { Share of adult population with only lower secondary } \\
\text { education level }\end{array}$ & & & $\begin{array}{c}-0.4886^{* * *} \\
(-3.79)\end{array}$ \\
\hline Growth rate of firms & $\begin{array}{c}2.4151^{* *} \\
(2.36)\end{array}$ & & \\
\hline Rate of openness of the economic system & $\begin{array}{c}0.0540 * \\
(1.81)\end{array}$ & & \\
\hline Constant & $\begin{array}{c}33.4967 * * * \\
(18.49) \\
\end{array}$ & $\begin{array}{c}1.3346^{* * *} \\
(2.93) \\
\end{array}$ & $\begin{array}{c}37.3239 * * * \\
(5.36)\end{array}$ \\
\hline $\mathrm{R}$-squared & 0.5122 & 0.6271 & 0.7742 \\
\hline
\end{tabular}

Nore: $* * \mathrm{p}<0.05 ; * * * \mathrm{p}<0.01$

Source: own processing

Table 7: Regression results.

In particular, the Value Added per hectare is highly affected by the intensive use of land, but also by management strategies directed to diversification, product processing and quality products. The negative sign of the second component (Quality of resources and market orientation) can be explained by the effect of some characteristics that enter in the second Principal Component, in particular the share of land covered by cereals. The only exogenous variable that enters in the model is the road infrastructure index with a positive sign.

More interesting is the Value Added per farm model. In this case the level of professionalism is a major factor affecting farm performance, along with the quality of resources and market orientation component. Moreover, the farm performance depends on the ICT services index at provincial level, with a positive sign, and on the share of population with only lower secondary education level, with negative sign.

\section{Conclusion}

The work was aimed at analysing farm characteristics and their relation with territorial features in determining the economic performance and competitiveness of the agricultural sector at NUTS3 level. Despite agricultural land use in Europe has deeply changed over last years, agricultural surfaces are still significant high. The question for the future is what will happen in agricultural land use, farming models and land abandonment processes. That will strongly depend on farms' competitiveness, on one side, and on how agriculture will be able to undertake a multifunctional pattern and to answer to changes in consumption models, on the other side. These factors are related to agricultural characteristics that vary at territorial level.

As Italian agriculture is concerned, the results of the present work allow drawing three main considerations. 
Firstly, the picture of Italian agriculture is very diversified and great territorially differences exist both in terms of productivity and performance indicators and in terms of management strategies, farming typologies and level of professionalism. In particular, the strong dichotomy that characterizes the economic systems of Northern and Southern Italy can still be found with reference to farm performance. Therefore, even if it is not so easy to identify a real pattern of the agriculture development, a strong relationship between agricultural systems and economic indicators is feasible.

Secondly, the determinants of agricultural productivity and performance are mainly endogenous to the sector and only few context indicators are statistically significant as explanatory variables. As a matter of fact, the dynamicity of the economic context is related to the agricultural labour productivity and the endowment in ICT infrastructure and human level of education play a role when considering farm value added, but the relevance given by the theory to drivers of competitiveness such as human and social capital, economic infrastructures, innovation rate was not generally verified. This result could depend on the indicators selected as proxies of agricultural productivity but it can depend on the territorial level of the analysis, too. On one side, Italian provinces still include very diversified agricultures and socio-economic conditions and thus taking into account average data flattens the information and reduces the explanatory power of analysis. On the other side, the territorial level where the interactions of economic and social phenomena operate and their effects emerge is not really known and might be different according to the specific aspect under analysis. In our study the NUTS 3 level might not be appropriate to catch the relationship between territory characteristics and agricultural performance.

A last consideration concerns implications of results on policy intervention. Results of the regression models confirm the role the new rural policy gives to factors such as food chain organisation and human capital quality (young farmers and high level of education). Agriculture structural characteristics and the level of commitment in the agricultural activity play a relevant role, too. At the same time, diversification strategies are relevant to land productivity, but do not affect labour productivity and the farm performance as a whole. That underlines the need for a deeper focus on structural factors by the policy intervention. A competitive and viable agriculture requires adequate farms' dimensions, professionalism, orientation to the market. Policies to support the farm's diversification can help its sustainability in the short term, but without a structural adjustment are not able to maintain a viable competitive activity in the long term.

Moreover, even if only few indicators of the socioeconomic context were relevant in the regression analysis to explain territorial productivity differences, the dichotomy of Northern and Southern Italy of both the economic systems and the agricultural productivity values (in terms of value added per farm) underlines a link between these two aspects. That implies the need of an integrated policy approach. The integration in the programming as well in the implementation phase requires higher attention to endogenous and exogenous factors that can constrain the agricultural and rural development and the adoption of a holistic vision in the definition and carrying out of policy measures.

Corresponding authors:

Giuseppe Di Vita, Research Assistant

Department of Agriculture, Food and Environment (Di3A), University of Catania

Via Santa Sofia, 100, 95123 Catania, Italy

E-mail: gvitae@hotmail.com

\section{References}

[1] Abdi, H. and Williams L. J. (2010) "Principal Component Analysis", Wiley Interdisciplinary Reviews: Computational Statistics, Vol. 2, No. 4, pp. 433-459. E-ISSN 1939-0068. DOI 10.1002/wics.101.

[2] Adrian, A., Norwood S. and Mask P. (2005) "Producers' perceptions and attitudes toward precision agriculture technologies“, Computers and Electronics in Agriculture, Vol. 48, No. 3, pp. 256- 271. ISSN 0168-1699. DOI 10.1016/j.compag.2005.04.004. 
[3] Ahearn, M. C., Yee, J. and Korb, P. (2005) "Effects of differing farm policies on farm structure and dynamics", American Journal of Agricultural Economics, Vol. 87, No. 5, pp. 1182-1189. E-ISSN 1467-8276, ISSN 0002-9092. DOI 10.1111/j.1467-8276.2005.00805.x.

[4] Amit, R. and Schoemaker, P. J. H. (1993) "Strategic Assets and Organizational Rent", Strategic Management Journal, Vol. 14, No. 1, pp. 33-46. E-ISSN 1097-0266. DOI 10.1002/smj.4250140105.

[5] Balk, B. M. (2001) "Scale efficiency and productivity change", Journal of Productivity Analysis, Vol. 15, pp. 159-183. E-ISSN 1573-0441, ISSN 0895-562X. DOI 10.1023/A:1011117324278.

[6] Bartolini, F. and Viaggi, D. (2013) "The common agricultural policy and the determinants of changes in EU farm size", Land Use Policy, Vol. 31, pp. 126-135. ISSN 0264-8377. DOI 10.1016/j.landusepol.2011.10.007.

[7] Budd, L. and Hirmis, A. (2004) "Conceptual framework for regional competitiveness", Regional Studies, Vol. 38, No. 9, pp. 1015-1028. E-ISSN 1360-0591, ISSN 0034-3404. DOI $10.1080 / 0034340042000292610$.

[8] Camagni, R. (2002) "On the concept of territorial competitiveness: sound or misleading?" Urban Studies, Vol. 39, No. 13, pp. 2395- 2411. E-ISSN 1360-063X, ISSN 0042-0980. DOI $10.1080 / 0042098022000027022$.

[9] Capello, R., Caragliu, A. and Nijkamp, P. (2011) "Territorial capital and regional growth: increasing returns in Knowledge use", Tijdschrift voor Economische en Sociale Geografie, Vol. 102, No. 4, pp. 385-405. E-I SSN 1467-9663. DOI 10.1111/j.1467-9663.2010.00613.x.

[10] Carillo, F., Carillo, M.R., Venittelli, T. and Zazzaro, A. (2013) "Aging and succession on Italian farms", Politica Agricola Internazionale-International Agricultural Policy, Vol. 1, pp. 39-55. ISSN 1722-4365.

[11] Cooper, A.C. and Gimeno Gascón, F.J. (1992) "Entrepreneurs, Processes of Founding, and New Firm Performance", in: D. Sexton and L. Kasarda (eds.) The State of the Art in Entrepreneurship. Boston, MA: PWS Kent Publishing Co: 301-340.

[12] Corsi, A. (2009) "Giovani e capitale umano in agricoltura", Agriregionieuropa, Vol.16, pp. 7-9. ISSN 1828-5880.

[13] D'Amico, M., Coppola, A., Chinnici, G., Di Vita, G. and Pappalardo, G. (2013) “Agricultural systems in the European Union: an analysis of regional differences", New Medit, Vol. 12, No. 4, pp. 28-34. ISSN 1594-5685.

[14] De Lillo, A., Argentin, G., Lucchini, M., Sarti, S. and Terraneo, M. (2007) Analisi multivariata per le scienze sociali, Pearson Paravia Bruno Mondadori, Piacenza. ISBN 978-88-7192-376-5.

[15] De Rosa, M., Bartoli, L. and Chiappini, S. (2013) "The adoption of agricultural extension policies in the Italian farms", New Medit, Vol. 12, No. 3, pp. 20-27. ISSN 1594-5685. DOI $10.13140 / 2.1 .1226 .3049$.

[16] Di Vita, G., Allegra, V., Zarbà, A. S. (2015) "Building scenarios: a qualitative approach to forecasting market developments for ornamental plants", International Journal of Business and Globalisation, Vol. 15, No. 2, pp. 130-151. E-ISSN 1753-3635, ISSN 1753-3627. DOI 10.1504/IJBG.2015.071152.

[17] Di Vita, G., Chinnici, G., Pappalardo, G., D'Amico, M. and Bracco, S. (2014) "Standard output versus standard gross margin, a new paradigm in the EU farm economic typology: what are the implications for wine-grape growers?" Journal of Wine Research, Vol. 25, No. 4, pp. 229-242. E-ISSN 1469-9672, ISSN 0957-1264. DOI 10.1080/09571264.2014.959660.

[18] Doss, C. R. and Morris, M. L. (2000) "How does gender affect the adoption of agricultural innovations?", Agricultural Economics, Vol. 25, No. 1, pp. 27-39. E-ISSN 1574-0862. DOI 10.1111/j.1574-0862.2001.tb00233.x.

[19] Esposti, R. (2011) "Convergence and divergence in regional agricultural productivity growth: evidence from Italian regions, 1951-2002”, Agricultural Economics, Vol. 42, No. 2, pp. 153-169. E-ISSN 1574-0862. DOI 10.1111/j.1574-0862.2010.00508.x. 
[20] Fagerberg, J. (1996). Technology and competitiveness", Oxford Review of Economic Policy, Vol. 12, No. 3, pp. 39-51. E-ISSN 1460-2121, ISSN 0266-903X. DOI 10.1093/oxrep/12.3.39.

[21] Fried, H. O., Schmidt, S. S. and Yaisawarng, S. (1999) "Incorporating the operating environment into a non parametric measure of technical efficiency", Journal of productivity analysis, Vol. 12, pp. 249- 267. E-ISSN 1573-0441, ISSN 0895-562X. DOI 10.1023/A:1007800306752.

[22] García Álvarez-Coque, J. M., López-García Usach, T. and Sanchez García, M. (2013) "Territory and innovation behaviour in agri-food firms: does rurality matter?", New Medit, Vol. 12, No. 3, pp. 2-10. ISSN 1594-5685.

[23] Gellynck, X., Vermeire, B. and Viaene, J. (2007) "Innovation in food firms: contribution of regional networks within the international business context, Entrepreneurship and Regional Development: An International Journal, Vol. 19, No. 3, pp. 209-226. E-ISSN 1464-5114, ISSN 0898-5626. DOI 10.1080/08985620701218395.

[24] Geroski, P. A. (1998). An Applied Econometrician's View of Large Company Performance, Review of Industrial Organization, Vol. 13, No. 3, pp. 271-293. E-ISSN 1573-7160, ISSN 0889-938X. DOI 10.1023/A:1007725026859.

[25] Halkos, G. E. and Tzeremes, N. G., (2007) "Productivity efficiency and firm size: An empirical analysis of foreign owned companies", International Business Review, Vol.16, No. 6, pp. 713-731. ISSN 0969-5931. DOI 10.1016/j.ibusrev.2007.06.002.

[26] Hall, B. F. and LeVeen, E. P. (1978) "Farm size and economics efficiency: the case of California", American Journal of Agricultural Economics, Vol. 60, No. 4, pp. 589-600. E-ISSN 1467-8276, ISSN 0002-9092. DOI 10.2307/1240243.

[27] Kaiser, H. F. (1958) "The VARIMAX criterion for analytic rotation in factor analysis", Psychometrika, Vol. 23, No. 3, pp. 187-200. E-ISSN 1860-0980, ISSN 0033-3123. DOI 10.1007/BF02289233.

[28] Kaiser, H. F. (1960) "The application of electronic computers to factor analysis", Educational and Psychological Measurement, Vol. 20, No. 1, pp. 141-151. E-ISSN 1552-3888, ISSN 0013-1644. DOI 10.1177/001316446002000116.

[29] Kaiser, H. F. and Rice, J. (1974) “Little Jiffy Mark IV”, Educational and Psychological Measurement, Vol.34,No. 1,pp.111-117. E-ISSN 1552-3888, ISSN0013-1644.DOI 10.1177/001316447403400115.

[30] Krugman, P. R. (1996) "Making sense of the competitiveness debate", Oxford Review of Economic Policy, Vol. 12, No. 3, pp. 17-25. E-ISSN 1460-2121, ISSN 0266-903X. DOI 10.1093/oxrep/12.3.17.

[31] Latruffe, L. (2010) "Competitiveness, Productivity and Efficiency in the Agricultural and Agri-Food Sectors", OECD Food, Agriculture and Fisheries Papers, OECD Publishing, No. 30, 62 p. ISSN 18156797. DOI 10.1787/5km91nkdt6d6-en.

[32] Man, T. W.Y., Lau, T. and Chan, K. F. (2002) "The competitiveness of small and medium enterprises. A conceptualization with focus on entrepreneurial competencies", Journal of Business Venturing, Vol. 17, No. 2, pp. 123-142. ISSN 0883-9026. DOI 10.1016/S0883-9026(00)00058-6.

[33] Maskell, P. and Malmberg, A. (1999) "Localized learning and industrial competitiveness", Cambridge Journal of Economics, Vol. 23, No. 2, pp. 167-185. E-ISSN 1464-3545, ISSN 0309-166X. DOI 10.1093/cje/23.2.167.

[34] Mathijs, E. and Vranken, L. (2001) "Human Capital, Gender and Organisation in Transition Agriculture: Measuring and Explaining the Technical Efficiency of Bulgarian and Hungarian Farms", Post-Communist Economies, Vol. 13, No. 2, pp. 171-187. E-ISSN 1465-3958, ISSN 1463-1377. DOI 10.1080/14631370120052654.

[35] Nickel, S., Nicolitsas, D. and Dryden, D. (1997) "What makes firms perform well?" European Economic Review, Vol. 41, No. 3/5, pp. 783-796. ISSN 0014-2921. DOI 10.1016/S0014-2921(97)00037-8. 
[36] Niedertscheider, M. and Erb, K. (2014) "Land system change in Italy from 1884 to 2007: Analysing the North-South divergence on the basis of an integrated indicator framework", Land Use Policy, Vol. 39, pp. 366-375. ISSN 0264-8377. DOI 10.1016/j.landusepol.2014.01.015.

[37] OECD (2001) "Measuring productivity. Measurement of aggregate and industry-level productivity growth", OECD Manual. OECD, Paris 156 p. ISBN 9789264187375, 9264187375.

[38] Ondersteijn, C. J. M., Giesen, G. W. J. and Huirne, R. B. M. (2003) "Identification of farmer characteristics and farm strategies explaining changes in environmental management and environmental and economic performance of dairy farms", Agricultural Systems, Vol. 78, No. 1, pp. 31-55. ISSN 0308-521X. DOI 10.1016/S0308-521X(03)00031-3.

[39] Overall, J. E. and Klett, C. J. (1972) "Applied Multivariate Analysis", McGraw-Hill Co, New York. ISBN 100070479356, ISBN 139780070479357.

[40] Phillips, J. M., (1994) "Farmer Education and Farmer Efficiency: A Meta-Analysis", Economic Development and Cultural Change, Vol. 43, No. 1, pp. 149-165. DOI 10.1086/452139.

[41] Porter, M. E. (1990) "The Competitive Advantage of Nations", London: Macmillan. ISBN 0029253616.

[42] Prokopy, L. S., Floress, K., Klotthor-Weinkauf, D. and Baumgart-Getz, A. (2008) "Determinants of agricultural best management practice adoption: Evidence from the literature", Journal of Soil and Water Conservation, Vol. 63, No. 5, pp. 300-311. E-ISSN 1941-3300, ISSN 0022-4561. DOI 10.2489/jswc.63.5.300.

[43] Scherer, F. M. (1991) "Changing perspectives on the firm size problem", in: Acs, Z. J. and D. B. Audretsch (eds.) "Innovation and technological change: An international comparison", University of Michigan Press.

[44] Schumpeter, J. A. (1934) "The theory of economic development", Harvard Economic Studies 46, Cambridge, Mass. ISBN 9780674879904.

[45] Seth, A. (1990) "Value creation in acquisitions: A re-examination of performance issues", Strategic Management Journal, Vol. 11, No. 2, pp. 99-115. E-ISSN 1097-0266. DOI 10.1002/smj.4250110203.

[46] Solano, C., León, H., Pérez, E., Tole, L., Fawcett, R. and Herrero, M. (2006) “Using farmer decisionmaking profiles and managerial capacity as predictors of farm management and performance in Costa Rican dairy farms", Agricultural Systems, Vol. 88, No. 2/3, pp. 395-428. ISSN 0308-521X. DOI 10.1016/j.agsy.2005.07.003.

[47] van Der Ploeg, J. D. and Roep, D. (2003) "Multifunctionality and rural development: the actual situation in Europe", in: van Huylenbroeck G. and G. Durand (eds) "Multifunctional Agriculture. A new paradigm for European agriculture and Rural Development", Ashgate, Burlington, VT (USA) e Aldershot (UK). ISBN 0754635767. 